\title{
Audit Studies of Housing in the United States: Established, Emerging, and Future Research
}

\author{
S. Michael Gaddis ${ }^{1,2}$ and Nicholas V. DiRago ${ }^{1,2}$ \\ May 2021 Draft \\ The Sociology of Housing \\ Editors: Brian J. McCabe and Eva Rosen
}

\begin{abstract}
Since the 1960s, social scientists, fair housing agencies, and the federal government have conducted hundreds of in-person and correspondence housing audits. Researchers use these covert experiments to make strong causal claims about difficult-to-detect behavior, such as racial, gender, and other types of discrimination. These studies have consistently uncovered discrimination in multiple stages and contexts of the housing exchange process. The housing audit literature is broad and robust, and a number of in-depth reviews already exist. In this chapter, we build on those reviews by focusing attention on emerging areas of inquiry and suggest new avenues of research pursuits. We begin by briefly reviewing the long history of housing audits including in-person HUD audits and correspondence audits of home sales and housing rentals. Next, we discuss three emerging areas of housing audit research - housing choice vouchers, short-term rentals, and roommate searches - and highlight important findings, new innovations, and areas of weakness. Finally, we conclude with a discussion about future directions of housing audits including using experiments to test for ways to reduce discrimination, using additional data to examine the mechanisms of housing discrimination, and designing modified audits to explore discrimination in other stages of housing exchange.
\end{abstract}

Keywords: discrimination, housing, audit studies, field experiments, inequality

Acknowledgments: This project was supported in part by the California Center for Population Research at the University of California, Los Angeles (UCLA) with training support (T32HD007545) and core support (P2CHD041022) from the Eunice Kennedy Shriver National Institute of Child Health and Human Development (NICHD). The content is solely the responsibility of the authors and does not necessarily represent the official views of the NICHD or the National Institutes of Health.

1 - Department of Sociology, University of California - Los Angeles

2 - California Center for Population Research, University of California - Los Angeles 


\section{INTRODUCTION}

Over the past six decades, researchers have increasingly used a field experiment known as the audit method to examine discrimination across disciplines, geography, characteristics, and contexts (Auspurg, Schneck, and Hinz 2019; Bertrand and Mullainathan 2004; Costa 2017; Gaddis 2015; 2018a; 2018b; Quillian et al. 2017; 2019). Researchers use these covert experiments to make strong causal claims about difficult-to-detect behavior, such as racial, gender, and other types of discrimination. Prior to the 2000s, audits were mostly conducted inperson and subject to high costs and complex implementation. Now, audits have become more common due to the rise of online applications for housing and employment and easy access to decision-makers across many contexts via email.

Fair housing committees, activists, and other private organizations began conducting housing audits in the 1940s (Cherry and Bendick 2018). The U.K. Parliament authorized a major housing audit to examine discrimination on the basis of race and immigration in England in the late 1960s (Daniel 1968). Since then, the U.S. Department of Housing and Urban Development (HUD) has conducted four $(1977,1989,2000,2012)$ large scale in-person audits of purchase and rental markets across the U.S. (Bavan 2007; Oh and Yinger 2015; Ross and Turner 2005; Turner et al. 2002; 2013; Wienk et al. 1979; Yinger 1995). Additionally, other researchers have conducted smaller scale in-person housing audits (see Galster 1990a; 1990b_ Yinger 1986), but the vast majority of housing audits in the last two decades have been correspondence audits those conducted online or via telephone, fax, or mail (Auspurg, Schneck, and Hinz 2019; Gaddis 2018a; Quillian, Lee, and Honoré 2020).

Although housing audits originally focused on examining differences by race as a means of investigating the effectiveness of the Civil Rights Act of 1968, researchers have expanded 
housing audits to examine discrimination on the basis of gender (Ewens, Tomlin, and Wang 2014; Hogan and Berry 2011), sexual orientation (Ahmed and Hammarstedt 2008; Murchie and Pang 2018; Schwegman 2019), parenthood (Galster and Constantine 1991), disability (Ameri et al. 2019; Turner et al. 2005), criminal record (Evans, Blount-Hill, and Cubellis 2019), and immigrant generational status (Gaddis and Ghoshal 2020b), among other characteristics. Research has examined a variety of outcomes including whether inquiries received a basic response, what type of information was provided, and whether inquirers were steered to other

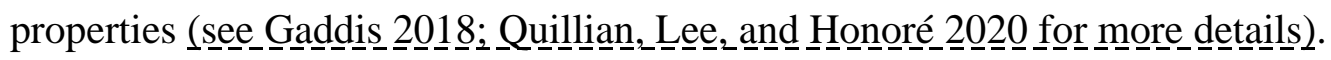

The housing audit literature is broad and robust, and a number of in-depth reviews already exist. In this chapter, we build on those reviews by focusing attention on emerging areas of inquiry and suggest new avenues of research pursuits. ${ }^{1}$ We begin by briefly reviewing the long history of housing audits including in-person HUD audits and correspondence audits of home sales and housing rentals. Next, we discuss three emerging areas of housing audit research - housing choice vouchers, short-term rentals, and roommate searches - and highlight important findings, new innovations, and areas of weakness. Finally, we conclude with a discussion about future directions of housing audits including using experiments to test for ways to reduce discrimination, using additional data to examine the mechanisms of housing discrimination, and designing modified audits to explore discrimination in other stages of housing exchange.

\section{ESTABLISHED RESEARCH}

\section{The HUD Studies}

The first HUD housing audit, known as the Housing Market Practices Survey (HMPS), used White and Black testers to examine discrimination in both the sale and rental housing

\footnotetext{
${ }^{1}$ Although we focus on housing audits only in the United States, our key points from the literature and suggestions for future work are broadly applicable.
} 
markets (Wienk et al. 1979). ${ }^{2}$ Researchers found discrimination against Black testers in reported housing availability, treatment by real estate agents, reported terms and conditions, and the types and levels of information requested by real estate agents. Subsequent HUD-sponsored audits were conducted by the Urban Institute and known as the Housing Discrimination Study (HDS), followed by the year they were conducted. Each HDS included an increasingly larger number of audits - 3,800 in 1989, 4,600 in 2000, and 8,047 in 2012, compared to 3,264 in the original HMPS. The HDS1989 added tests for Hispanics and examined racial steering (Turner, Struyk, and Yinger 1991). The HDS2000 added tests for Asians and Native Americans (Ross and Turner 2005; Turner and Ross 2003; Turner et al. 2002; 2003) and a small follow-up supplement to test for discrimination in rental housing on the basis of disability (Turner et al. 2005). Finally, the HDS2012 included all previously examined racial/ethnic groups except Native Americans (Turner et al. 2013), and again included an examination of housing discrimination on the basis of disability (Levy et al. 2015) . Each of the HDS studies found racial/ethnic and disability discrimination across many dimensions in sale and rental housing markets.

Recent HUD-sponsored studies have added correspondence audits and other characteristics such as sexual orientation (Levy et al. 2017; Turner et al. 2013). In a special issue of Cityscape focusing on housing discrimination (Turner and James 2015), Claudia L. Aranda (2015) of the Urban Institute reviews the HDS disability discrimination findings, while Sun Jung Oh and John Yinger (20ㅡ몬) provide an extensive review of the HMPS and HDS racial/ethnic discrimination findings.

\section{Other In-Person and Correspondence Audits of Home Sales and Rentals}

Researchers and fair housing organizations conducted numerous small sample size inperson housing audits from the 1970s (pre-dating the HMPS) through the early 2000s. Most of

\footnotetext{
${ }^{2}$ An extension of the HMPS examined housing discrimination against Hispanics in Dallas (Hakken 1979).
} 
these studies document racial discrimination against Black, and sometimes Hispanic, buyers and renters across multiple outcomes (Feins and Bratt 1983; Galster 1990b; 1990a; James, McCummings, and Tynan 1984). To our knowledge, only two published non-HUD audits from this period of over thirty years in the U.S. examined housing discrimination on the basis of a characteristic other than race/ethnicity. Galster and Constantine (11991) examined rental housing discrimination on the basis of gender and parenthood, and found that single women with and without children faced significant discrimination compared to men. Additionally, in an analysis of Boston audit data, Yinger (1 $19 \underline{9} \underline{6}$ ) found that couples with young children faced slight discrimination compared to single adults and couples with older children.

Following groundbreaking work by Devah Pager (22003), and Marianne Bertrand and Sendhil Mullainathan (2004), researchers began fielding more audits. These audits include new characteristics that might moderate levels of discrimination and test for different types of

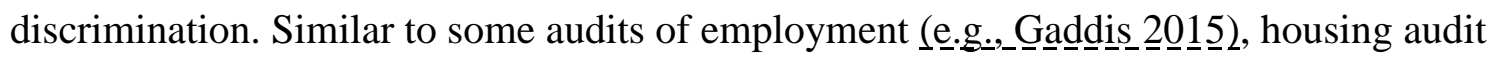
researchers have included social class signals (Hanson and Hawley 2011; Hanson, Hawley, and Taylor 2011) or credit scores (Ewens, Tomlin, and Wang 2014) to examine variation in racial/ethnic discrimination by SES. Others have included signals for criminal record and health conditions (Henkels 2020). Finally, researchers examine targets of discrimination through a wider range of racial/ethnic (Carpusor and Loges 2006), gender, and sexual orientation (Hellyer 2021; Murchie and Pang 2018; Schwegman 2019) statuses. We recommend consulting numerous prior reviews for more details (Auspurg, Schneck, and Hinz 2019; Flage 2018; Gaddis 2018a; Riach and Rich 2002; Rich 2014; Quillian, Lee, and Honoré 2020).

\section{EMERGING RESEARCH}

\section{Housing Choice Vouchers - "Section 8"}


Researchers have begun using audits to test for discrimination against tenants who pay for housing with the help of a Housing Choice Voucher (HCV), also known as “Section 8.” By subsidizing poor households' rent in privately owned units that meet basic safety standards, the HCV program reduces barriers to decent housing and promotes physical and financial security (Rosen 2020). Three gaps in the HCV program, however, have led to failure in the stated goal of facilitating social mobility for residents of poor neighborhoods. First, landlords often exclude voucher holders from affluent neighborhoods while seeking them out in low-income areas. Second, information is scarce on using HCVs to move to more advantaged neighborhoods. Third, Congress only funds HCVs for less than a quarter of eligible households (Moore 2016). Many analysts argue that reforming and expanding the HCV program would reduce housing

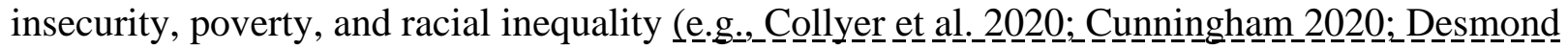
2016을 Rosen_2021). Critics caution against relying on discrimination-prone landlords in the private market to reduce housing inequality.

Experimental evidence of landlords’ discriminatory behavior toward HCV holders contributes to this debate. The most comprehensive audit of HCVs found that landlords discriminate by refusing vouchers altogether or prioritizing applicants without vouchers over voucher holders (Cunningham et al. 2018). HUD-commissioned researchers fielded a multi-stage experiment in five U.S. cities in 2016 and 2017. A White woman first responded by telephone to apartment advertisements and asked whether the landlord accepted HCVs. Paired ${ }^{3}$ White, Black, and Latinx women then attempted to schedule and appear at in-person appointments with purportedly HCV-friendly landlords in three of the five cities. In the first stage $(n=3,780)$,

\footnotetext{
${ }^{3}$ In paired testing, researchers send two or more applications or emails with different characteristics to the same subject or organization being audited (e.g., landlord, real estate agent, etc.). There can be statistical advantages to paired testing, however, in some cases it may be necessary to implement a non-paired test design to reduce suspicion and avoid experiment discovery (Gaddis 2013; 2015; Larsen 2020; Vuolo, Uggen, and Lageson 2016; 2018; Weichselbaumer 2015; 2020).
} 
landlords refused vouchers at widely varying rates, from 15 percent in Washington, DC, to over 75 percent in Los Angeles and Fort Worth. Landlords were more likely to refuse HCVs in more affluent neighborhoods. In the second stage ( $n=694)$, testers in the HCV and control groups had comparable success securing appointments by phone. In the third stage $(n=509)$, however, landlords were 12 percent more likely to appear at appointments scheduled with testers in the control group. Landlords also told testers in the HCV group about fewer or different available units.

Correspondence audits also provide evidence on statistical interactions between applicant race and voucher use, a possibility the HUD-commissioned study raises but does not test. In one experiment in Washington, DC, in 2015, landlords were over twice as likely to respond to applicants in the control group than those indicating HCV status (Phillips 2017). The penalty for voucher use increased with rental cost and was two to four times the penalty for Black applicants. The two penalties were additive and non-interactive. Researchers fielded a second wave in 2017, after local regulations were amended to allow higher HCV subsidies in costlier neighborhoods (Aliprantis, Martin, and Phillips 2019b; 2019a). The voucher penalty’s magnitude, positive association with rents, and additive relationship with the penalty for Black applicants were relatively stable, although new voucher holders were more likely to lease up in costlier neighborhoods after the regulations changed. A third audit across 14 cities found a comparable voucher penalty and a similarly additive, non-interactive relationship between voucher status and race (Moore 2018). Overall, these results suggest that landlords discriminate on the basis of race and voucher status, but generally do not use these characteristics as proxies for one another when determining whether to accept HCVs. 
The HUD-commissioned study provisionally attributes variation in rates of voucher refusal to the strength of local anti-discrimination laws. Only one audit has tested this hypothesis directly, providing preliminary supporting evidence (Moore 2018). Messages indicating HCV status were roughly five percentage points more likely to receive a positive response in cities where anti-voucher discrimination was illegal, controlling for characteristics of the advertisement, housing unit, neighborhood, and local housing market. This result, however, is vulnerable to confounding from local voucher payment levels and other variable aspects of local implementation. Although local laws may attenuate levels of discrimination against HCV holders, these laws are unlikely to completely eliminate discrimination.

\section{Short-Term Rentals}

Several audit studies analyze short-term rentals (STRs), which last less than a month and are typically booked online by tourists. The largest, most studied platform for STRs is Airbnb. In sociology, researchers usually approach STRs as cases of political and economic restructuring (Vallas and Schor 2020). Sociologists of housing have focused mainly on links among STRs, speculation, rents, and neighborhood change (Hoffman and Heisler 2021). As emerging audit research demonstrates, however, STRs also reveal largely unexamined mechanisms of discrimination and the shortcomings of policies designed to reduce it (see_ Cheng__and Foley 2018).

Two correspondence audits have examined racial discrimination on Airbnb. The first examined host responses in five cities in 2015; landlords accepted 42 percent of requests from Black applicants, compared to 50 percent from White applicants (Edelman, Luca, and Svirsky 2017). A relatively distinct subset of serially discriminatory landlords accounted for the bulk of this 16-percent disparity, which varied little with housing units' and landlords' characteristics. 
This audit, public awareness of discrimination on the platform, and a series of lawsuits led Airbnb to change their policy in requiring guests to include a photograph and their full name before completing a booking (Murphy 2016; Schor and Vallas 2021; "Settlement Reached in Airbnb Discrimination Case” 2019). A second study, conducted from 2016 through 2018, also explored five U.S. cities, though only one city appears in both studies (Cui, Li, and Zhang 2020). A comparable 19-percent disparity emerged between Black and White applicants. When applicants' profiles included positive reviews from past STR hosts, however, new hosts did not discriminate against Black applicants.

There is also experimental evidence of ableism in STRs in the U.S. In a correspondence audit of Airbnb in 2016, hosts were between 18 and 67 percent less likely to pre-approve requests from applicants indicating they needed accommodations for a disability than from paired control applicants (Ameri et al. 2019). Levels of discrimination varied by the disability indicated and accommodations requested, but they were robust to the onset of non-discrimination policies and consistent across housing unit characteristics. The authors argue their findings reveal a gap in the Americans with Disabilities Act, which protects individuals with disabilities from discrimination in hotels but not STRs.

\section{Roommate Searches}

Another new area of housing correspondence audits examines the process of roommate selection. Nearly six percent of the U.S. adult population -- more than 15 million people -currently live with unrelated roommates who are not a romantic partner (U.S. Census Bureau 2017), and the total number to ever live with a roommate is likely much higher. Roommate selection is an even more integral part of the housing search process for the young and highly educated; 16 percent of individuals with at least a bachelor's degree who are in their 20s live 
with a roommate (Lauff and Ingels 2013). Thus, roommate correspondence audits capture a very different housing search process for the young, geographically mobile, and highly educated demographic who move to costly urban areas and often cannot rent, much less purchase, housing units on their own (Olsen 2014). Compared to older individuals, less educated individuals, and those with families, myriad economic and social issues influencing the housing search process are likely important to different degrees or not at all. Still, the decisions these individuals make influence segregation, access to resources, commute times, and the overall quality of their neighborhoods for themselves and others, and in turn influence future downstream outcomes as well.

Two published studies examine roommate discrimination via correspondence audits. In each study, the authors respond to individuals who post advertisements on Craigslist looking for roommates (Gaddis and Ghoshal 2015; 2020b). ${ }^{4}$ Each ad represents an individual who already lives with one or more roommates and is looking for a new person to fill a recently or soon-to-be vacated room. In the first study, the authors respond to advertisements in Detroit, Houston, Los Angeles, and New York City using White and Arab American names (Gaddis and Ghoshal 2015). The authors find that Arab American room-seekers are only 57 percent as likely as White room-seekers to receive a response to their inquiries. These disparities differ by geography; they are largest in New York and smallest in Los Angeles. Additionally, the authors find tentative evidence supporting the ethnic competition hypothesis; Arab American room-seekers experience higher discrimination in some cities when listings are in areas with high population concentrations of Arabs and in close proximity to mosques. In the second study, the authors respond to advertisements in Boston, Chicago, and Philadelphia using White, Black, Hispanic,

\footnotetext{
${ }^{4}$ In addition, two survey experiments examine the mechanisms of roommate discrimination (Gaddis and Ghoshal 2020a; Lu et al. 2021).
} 
and Asian American names with different versions of ethnic or White/Anglo first and last names to signal immigrant generational status (Gaddis and Ghoshal 2020b). The authors find that Whites room-seekers receive the most responses, followed by 2nd and later generation Asian and Hispanic room-seekers, then 1-1.5 generation Asian and Hispanic room-seekers, and finally Black room-seekers receive the fewest responses. Thus, these studies find significant racial discrimination against a number of racial/ethnic groups in an increasingly important area of housing, particularly for young people in urban areas.

\section{FUTURE RESEARCH}

\section{Research Design and Conceptualization}

\section{Methodological Concerns When Designing Audits}

Researchers who wish to conduct their own housing audit should be aware of at least two major concerns when designing an audit. Recent methodological work in these areas provides researchers with blueprints for design that were not available even just a few years ago. First, recent work has examined the decision of how many applications or emails a researcher should submit in an audit. Conventional wisdom suggests that a paired design is more statistically efficient, decreases the amount of time required for data collection, and can lead to a larger sample size (Lahey and Beasley 2018). Recent work, however, suggests this design choice is more nuanced and paired audits are not needed as often as researchers think (Vuolo, Uggen, and Lageson 2016; 2018). Additionally, researchers have raised concerns that paired designs may influence findings of discrimination because researchers insert fake applicants into the applicant pool without knowing the composition of that applicant pool (Larsen 2020; Phillips 2019).

Second, scholars have examined the validity of using names to signal a host of characteristics, including age, social class, race/ethnicity, and immigrant generational status. 
Researchers often must use names to indirectly signal these characteristics when they cannot use more direct signals (e.g., explicit statement, photos). Early work occasionally raised questions about the validity of these signals (Bertrand and Mullainathan 2004; Fryer and Levitt 2004). In the last few years, scholars have produced a flurry of work addressing this issue (Butler and Homola 2017; Crabtree and Chykina 2018; Gaddis 2017a; 2017b; 2019a; 2019b; Ghoshal 2019; Johfre 2020). This research shows that racial perceptions of White and Black names are often linked with social class (Gaddis 2017a; 2019b), and that racial perceptions of Hispanic and Asian names are linked with immigrant generational status (Gaddis 2019a).

\section{External Validity: Whose Experiences are Researchers Capturing?}

Correspondence audits represent a strangely specific type of research design. Wellexecuted audit studies have high internal validity and can capture a very real experience in precise contexts (e.g., for people who use Craigslist to look for a rental unit). However, audits often capture only one of the ways individuals commonly engage in a given stage of the housing exchange process (e.g., initial emails with a landlord and no face-to-face contact). Researchers should take sampling bias seriously and distinguish between two aspects of external validity: the realism of the scenario and the generalizability of the scenario. ${ }^{5}$

Especially in emerging areas of research, few studies identify exactly who are the populations of interest, address the extent to which their data represent them, and analyze data or interpret results accordingly. Instead, many studies take for granted the populations that use housing listing services, STR platforms, and other common sources of data for audits. Moreover, audits never account for individual preferences and choices in the search processes they claim to mimic. These decisions may also be in anticipation of racial discrimination or due to existing

\footnotetext{
${ }^{5}$ Some of the issues presented in this section are also discussed in detail in a special issue of Cityscape (Friedman 2015; Turner 2015). Relatedly, issue of timing in sample selection may influence a study's results (Auspurg, Schneck, and Thiel 2020).
} 
residential segregation patterns. Some authors would argue their studies are primarily concerned with internal validity: broadly representing real-world processes and populations matters less than causal identification within the sample.

Yet audits have potential contributions beyond estimating causal effects. Researchers often wish to help identify illegal or discriminatory behavior in support of reforms that would curb it or to assess existing anti-discrimination policies. For example, a study's motivation, and many policymakers' concern, might be to identify how much anti-Black discrimination occurs in low-income rental housing markets in U.S. cities and what policies can mitigate it. A given study's data may only enable authors to identify, say, a disparity of x percent that surfaces in paired responses to Craigslist advertisements for apartments in the cheapest quartile in five large cities. Researchers could bridge this well-identified causal effect to the larger questions that will draw many readers to the study by marshalling supplemental data or consulting existing theoretical, quantitative, and qualitative research. How representative of populations of interest are Craigslist users in the low-income housing market in the five sampled cities? Based on demographic composition, political and economic arrangements, and pertinent historical dynamics, how representative are these five cities of U.S. cities?

Researchers should be explicit about their limited scope and walk readers through the assumptions or further research that would be necessary to link a study's findings to broader scientific and political questions. In some cases, findings readily generalize to the places and populations of interest. In other cases, generalizability is more clearly limited. Most of the time, whether a study is generalizable is hazy. Researchers can do more, however, than enumerate limitations at the end of an article. They can treat them as part of the study's mandate and 
address them head-on by assessing the study's external validity and arguing for the interpretation they find most plausible.

The Stages of Housing Exchange and In-Person Testing

Future audit studies of housing in the U.S. should reflect more clearly that discrimination compounds over the multiple, heterogeneous, and path-dependent stages of housing exchange (Bell 2020; DeLuca, Wood, and Rosenblatt 2019; Harvey et al. 2020; Korver-Glenn 2018; 2021; Krysan and Crowder 2017). Audit methods can measure discrimination in some stages but are inappropriate for others. For some auditable stages of housing exchange, in-person testing is the only viable route to experimental data. Regardless of the stages any given study examines, however, audit researchers should aim for more than quantifying the magnitude of discrimination. Guided by theory and empirical research, they should present audits' findings and limitations in view of the wider process of housing exchange.

Some stages of housing exchange are amenable to audit studies in principle but difficult to audit in practice because verisimilitude is difficult to achieve. For example, researchers might wish to audit rental or mortgage applications, which usually collect confidential data to screen applicants' incomes, credit scores, residential histories, encounters with the legal system, etc. Audit researchers would have to coordinate with a prohibitive number of actors to ensure testers' applications return convincing results. For the foreseeable future, observational studies are better suited to analyzing stages of housing exchange that involve third parties and personal or proprietary data. By extension, audit studies are also infeasible for many subsequent stages that housing searchers reach only conditional on success in earlier stages that are hard to audit.

Although correspondence studies are increasingly popular approaches to the auditable stages of housing exchange, in-person audits with live testers remain vital to comprehensive 
experimental data on housing discrimination. Today, researchers can increasingly field correspondence audits cheaply online. They can also achieve considerable external validity because many stages of housing exchange often transpire without in-person interaction. Correspondence audits, however, are not well-suited to every stage of housing exchange in the U.S. Many stages continue to occur primarily in person, especially unit showings. Individuals are susceptible to discrimination in these stages. Relying on correspondence studies over-represents earlier and more impersonal stages of housing exchange in the literature at the expense of later and more interactive stages. Researchers should prioritize, and funders should increase resources for, auditing face-to-face and in-person interactions in housing markets about which automated or remote data collection is impossible. Some studies might reasonably focus on single stages. Following testers through multiple stages of housing exchange, however, perhaps by combining correspondence and in-person testing, will better capture the contours of discrimination. In turn, researchers can compare outcomes across stages, identifying more definitively the points at which housing discrimination is most prevalent or impactful.

Even large, multi-stage experiments with in-person testing capabilities, however, cannot exhaustively audit the stages of housing exchange at which gatekeepers can discriminate. Researchers should continue collecting more and better data, but they cannot substitute for theory and careful interpretation. Any audited interaction in the housing market is a slice of a broader process. At a minimum, researchers should explicitly state this limitation to avoid spurious conclusions about the generalizability of findings to more of the housing market or housing exchange process than they can reliably claim. A more robust approach, however, would be to interpret the implications of the discrimination, if any, that an audit uncovers in a stage or set of stages. In some respects, this interpretation is akin to the approach to external validity 
outlined above. Researchers should discuss what segments of the population are likely

participating in the given stage(s) and the extent to which testers represent them. More generally, researchers can contextualize their findings by considering the antecedent stages or experiences individuals through which individuals must go before reaching the audited stage(s) and how any discrimination they uncover shapes subsequent stages. This analytical orientation would expand audit studies' focus from questions of whether and how much discrimination occurs to questions of who experiences discrimination and why it matters.

\section{New Directions}

Can Scholars Test for Other Experimental Treatments to Reduce Discrimination?

Although correspondence audits are unique methodological tools used to examine the existence of discrimination, researchers have rarely used additional audit treatment conditions to test for mechanisms to reduce or eliminate discrimination. One such study in housing examined the effect of an informational call from a government agency reminding landlords of fair housing law and potential penalties for engaging in discrimination (Fang, Guess, and Humphreys 2019). The authors found that this intervention led to a small reduction in discrimination against Hispanic but not Black housing-seekers. Researchers tested this very specific intervention only in New York. Future research might test alternative interventions in a wider array of cities and housing contexts to more thoroughly examine whether policies and programs might help attenuate housing discrimination.

Can Scholars Learn More About the Mechanisms of and Reasons Behind Discrimination?

The correspondence audit method excels at providing information on the "what," "where," and "why," but comes up short in answering the "how" and "why” questions of discrimination (Gaddis 2019c). Scholars have suggested that the body of knowledge on 
processes of discrimination would benefit from coupling audit data with additional data sources such as survey or interview data (Gaddis 2018a; Pedulla 2018). Many such examples exist in the literature on discrimination in the labor market (Correll, Benard, and Paik 2007; Pedulla 2016; Quadlin 2018; Rivera and Tilcsik 2016), but none among housing discrimination studies. This is a significant oversight in the literature. Do landlords discriminate against Black or Hispanic housing-seekers due to assumptions about their ability to pay rent? Do hosts on STR platforms discriminate against disabled individuals due to perceived accessibility gaps in their dwelling? A well-designed correspondence audit coupled with interview or survey data might provide answers to these and other important questions about the mechanisms of discrimination. Can Scholars Implement Modified Audits to Examine Other Stages of Housing Exchange?

Promising new versions of the correspondence audit may present novel ways for researchers to examine discrimination in other stages of housing exchange. For example, to examine discrimination in college admissions, some researchers have emailed admissions counselors with basic questions (Brown and Hilbig 2021; Hanson 2017; Thornhill 2019). A normal correspondence audit, however, cannot examine actual admissions outcomes since a researcher would be forced to somehow fake key information like high school transcripts and SAT scores. A recent study found a creative way around this by recruiting real subjects who were matched on similar characteristics and then applied to colleges using their own accurate information (Stewart and Uggen 2020). This "modified audit” design could be used in housing studies of discrimination to, perhaps, examine the stages of mortgage approval, appraisals, and reference checks, among others.

\section{CONCLUSION}


Social scientists, fair housing agencies, and the federal government have conducted housing audits, both in-person and correspondence versions, to examine discrimination in the U.S. since the 1960s. These studies have consistently uncovered racial discrimination in multiple stages and contexts of the housing exchange process. In recent years, scholars have expanded audits to include additional characteristics and contexts. Beyond traditional housing rental and sale audits, research has started to examine discrimination across three emerging areas of audits: housing choice vouchers, short-term rentals, and roommate searches. These audits have uncovered new discrimination on the basis of race/ethnicity, SES, and disability status. Researchers looking to conduct their own housing audit should be aware of issues of pairing correspondence, signaling characteristics, and external validity. Additionally, while some stages of the housing exchange process lend themselves well to auditing, researchers should consider whether they can implement a modified audit in other stages to expand knowledge of discrimination in housing. Finally, future experiments should also include experimental treatments to test for ways to reduce discrimination and additional data beyond the experimental data to test for mechanisms of discrimination. If researchers follow these and other new paths, the next decade will likely bring significant advances in our understanding of housing discrimination. 


\section{REFERENCES}

Ahmed, Ali M., and Mats Hammarstedt. 2008. "Discrimination in the Rental Housing Market: A Field Experiment on the Internet.” Journal of Urban Economics 64 (2): 362-72. https://doi.org/10.1016/j.jue.2008.02.004.

Aliprantis, Dionissi, Hal Martin, and David Phillips. 2019a. "Can Landlords Be Paid to Stop Avoiding Voucher Tenants?” Federal Reserve Bank of Cleveland Working Papers, Working paper (Federal Reserve Bank of Cleveland), 19-02 (January). https://doi.org/10.26509/frbc-wp-201902.

_ 2019b. "Landlords and Access to Opportunity." Federal Reserve Bank of Cleveland Working Papers 19-02R2 (November). https://doi.org/10.26509/frbc-wp-201902r2.

Ameri, Mason, Sean Edmund Rogers, Lisa Schur, and Douglas Kruse. 2019. "No Room at the Inn? Disability Access in the New Sharing Economy.” Academy of Management Discoveries 6 (2): 176-205. https://doi.org/10.5465/amd.2018.0054.

Aranda, Claudia L. 2015. “Targeting Disability Discrimination: Findings and Reflections From the National Study on Housing Discrimination Against People Who Are Deaf and People Who Use Wheelchairs.” Cityscape 17 (3): 103-22.

Auspurg, Katrin, Andreas Schneck, and Thomas Hinz. 2019. “Closed Doors Everywhere? A Meta-Analysis of Field Experiments on Ethnic Discrimination in Rental Housing Markets.” Journal of Ethnic and Migration Studies 45 (1): 95-114. https://doi.org/10.1080/1369183X.2018.1489223.

Auspurg, Katrin, Andreas Schneck, and Fabian Thiel. 2020. "Different Samples, Different Results? How Sampling Techniques Affect the Results of Field Experiments on Ethnic Discrimination." Research in Social Stratification and Mobility, Experimental methods in social stratification research, 65 (February): 100444. https://doi.org/10.1016/j.rssm.2019.100444.

Bavan, Meena. 2007. "Does Housing Discrimination Exist Based on the 'Color' of an Individual's Voice?” Cityscape 9 (1): 93-107.

Bell, Monica C. 2020. "Located Institutions: Neighborhood Frames, Residential Preferences, and the Case of Policing." American Journal of Sociology 125 (4): 917-73. https://doi.org/10.1086/708004.

Bertrand, Marianne, and Sendhil Mullainathan. 2004. “Are Emily and Greg More Employable Than Lakisha and Jamal? A Field Experiment on Labor Market Discrimination.” American Economic Review 94 (4): 991-1013. https://doi.org/10.1257/0002828042002561.

Brown, Jacob R., and Hanno Hilbig. 2021. "Locked Out of College: When Admissions Bureaucrats Do and Do Not Discriminate.” British Journal of Political Science, February, 1-11. https://doi.org/10.1017/S0007123420000848.

Butler, Daniel M., and Jonathan Homola. 2017. "An Empirical Justification for the Use of Racially Distinctive Names to Signal Race in Experiments.” Political Analysis 25 (1): 122-30. https://doi.org/10.1017/pan.2016.15.

Carpusor, Adrian G., and William E. Loges. 2006. "Rental Discrimination and Ethnicity in Names1.” Journal of Applied Social Psychology 36 (4): 934-52. https://doi.org/10.1111/j.0021-9029.2006.00050.x. 
Cheng, Mingming, and Carmel Foley. 2018. "The Sharing Economy and Digital Discrimination: The Case of Airbnb.” International Journal of Hospitality Management 70 (March): 9598. https://doi.org/10.1016/j.ijhm.2017.11.002.

Cherry, Frances, and Marc Bendick. 2018. "Making It Count: Discrimination Auditing and the Activist Scholar Tradition.” In Audit Studies: Behind the Scenes with Theory, Method, and Nuance, edited by S. Michael Gaddis, 45-62. Methodos Series. Cham: Springer International Publishing. https://doi.org/10.1007/978-3-319-71153-9_2.

Collyer, Sophie, Christopher Wimer, Megan Curran, Katherine Friedman, Robert Paul Hartley, David Harris, and Andrew Hinton. 2020. "Housing Vouchers and Tax Credits:” Volume 4, Number 9. Poverty and Social Policy Brief. Center on Poverty and Social Policy at Columbia University.

Correll, Shelley J., Stephen Benard, and In Paik. 2007. “Getting a Job: Is There a Motherhood Penalty?” American Journal of Sociology 112 (5): 1297-1339. https://doi.org/10.1086/511799.

Costa, Mia. 2017. "How Responsive Are Political Elites? A Meta-Analysis of Experiments on Public Officials.” Journal of Experimental Political Science 4 (3): 241-54. https://doi.org/10.1017/XPS.2017.14.

Crabtree, Charles, and Volha Chykina. 2018. "Last Name Selection in Audit Studies.” Sociological Science 5 (January): 21-28. https://doi.org/10.15195/v5.a2.

Cui, Ruomeng, Jun Li, and Dennis J. Zhang. 2020. "Reducing Discrimination with Reviews in the Sharing Economy: Evidence from Field Experiments on Airbnb." Management Science 66 (3): 1071-94. https://doi.org/10.1287/mnsc.2018.3273.

Cunningham, Mary K. 2020. "It's Time to Reinforce the Housing Safety Net by Adopting Universal Vouchers for Low-Income Renters.” Urban Wire (blog). April 7, 2020. https://www.urban.org/urban-wire/its-time-reinforce-housing-safety-net-adoptinguniversal-vouchers-low-income-renters.

Cunningham, Mary K., Martha Galvez, Claudia L. Aranda, Robert Santos, Doug Wissoker, Alyse Oneto, Rob Pitingolo, and James Crawford. 2018. "A Pilot Study of Landlord Acceptance of Housing Choice Vouchers.” Washington, DC: U.S. Department of Housing and Urban Development. https://www.huduser.gov/portal/pilot-study-landlordacceptance-hcv.html.

Daniel, William Wentworth. 1968. Racial Discrimination in England: Based on the PEP Report. Penguin.

DeLuca, Stefanie, Holly Wood, and Peter Rosenblatt. 2019. "Why Poor Families Move (And Where They Go): Reactive Mobility and Residential Decisions.” City \& Community 18 (2): 556-93. https://doi.org/10.1111/cico.12386.

Desmond, Matthew. 2016. Evicted: Poverty and Profit in the American City. New York: Crown. Edelman, Benjamin, Michael Luca, and Dan Svirsky. 2017. "Racial Discrimination in the Sharing Economy: Evidence from a Field Experiment.” American Economic Journal: Applied Economics 9 (2): 1-22. https://doi.org/10.1257/app.20160213.

Evans, Douglas N., Kwan-Lamar Blount-Hill, and Michelle A. Cubellis. 2019. "Examining Housing Discrimination across Race, Gender and Felony History.” Housing Studies 34 (5): 761-78. https://doi.org/10.1080/02673037.2018.1478069.

Ewens, Michael, Bryan Tomlin, and Liang Choon Wang. 2014. "Statistical Discrimination or Prejudice? A Large Sample Field Experiment.” The Review of Economics and Statistics 96 (1): 119-34. https://doi.org/10.1162/REST_a_00365. 
Fang, Albert H., Andrew M. Guess, and Macartan Humphreys. 2019. "Can the Government Deter Discrimination? Evidence from a Randomized Intervention in New York City.” The Journal of Politics 81 (1): 127-41. https://doi.org/10.1086/700107.

Feins, Judith D., and Rachel G. Bratt. 1983. "Barred in Boston: Racial Discrimination in Housing.” Journal of the American Planning Association 49 (3): 344-55. https://doi.org/10.1080/01944368308976561.

Flage, Alexandre. 2018. "Ethnic and Gender Discrimination in the Rental Housing Market: Evidence from a Meta-Analysis of Correspondence Tests, 2006-2017.” Journal of Housing Economics 41 (September): 251-73. https://doi.org/10.1016/j.jhe.2018.07.003.

Friedman, Samantha. 2015. "Commentary: Housing Discrimination Research in the 21st Century.” Cityscape 17 (3): 143-50.

Fryer, Roland G., and Steven D. Levitt. 2004. "The Causes and Consequences of Distinctively Black Names.” The Quarterly Journal of Economics 119 (3): 767-805. https://doi.org/10.1162/0033553041502180.

Gaddis, S. Michael. 2013. A Matter of Degrees: Educational Credentials and Race and Gender Discrimination in the Labor Market. . 2015. "Discrimination in the Credential Society: An Audit Study of Race and College Selectivity in the Labor Market.” Social Forces 93 (4): 1451-79. https://doi.org/10.1093/sf/sou111. . 2017a. "How Black Are Lakisha and Jamal? Racial Perceptions from Names Used in Correspondence Audit Studies.” Sociological Science 4: 469-89. https://doi.org/10.15195/v4.a19. . 2017b. "Racial/Ethnic Perceptions from Hispanic Names: Selecting Names to Test for Discrimination.” Socius 3 (January): 2378023117737193. https://doi.org/10.1177/2378023117737193.

— . 2018a. "An Introduction to Audit Studies in the Social Sciences.” In Audit Studies: Behind the Scenes with Theory, Method, and Nuance, edited by S. Michael Gaddis, 3-44. Methodos Series. Cham: Springer International Publishing. https://doi.org/10.1007/9783-319-71153-9_1.

— ed. 2018b. Audit Studies: Behind the Scenes with Theory, Method, and Nuance. Cham: Springer International Publishing. https://doi.org/10.1007/978-3-319-71153-9. . 2019a. "Assessing Immigrant Generational Status from Names: Evidence for Experiments Examining Racial/Ethnic and Immigrant Discrimination.” SSRN Scholarly Paper ID 3022217. Rochester, NY: Social Science Research Network. https://doi.org/10.2139/ssrn.3022217. . 2019b. "Signaling Class: An Experiment Examining Social Class Perceptions from Names Used in Correspondence Audit Studies.” SSRN Scholarly Paper ID 3350739. Rochester, NY: Social Science Research Network. https://doi.org/10.2139/ssrn.3350739. . 2019c. "Understanding the 'How' and 'Why' Aspects of Racial-Ethnic Discrimination: A Multimethod Approach to Audit Studies.” Sociology of Race and Ethnicity 5 (4): 44355. https://doi.org/10.1177/2332649219870183.

Gaddis, S. Michael, and Raj Ghoshal. 2015. "Arab American Housing Discrimination, Ethnic Competition, and the Contact Hypothesis." The ANNALS of the American Academy of Political and Social Science 660 (1): 282-99. https://doi.org/10.1177/0002716215580095. 
. 2020a. "Dynamic Racial Triangulation: Examining the Racial Order Using an Experiment on Discrimination by White Millennials.” SSRN Scholarly Paper ID 3022208. Social Science Research Network. https://doi.org/10.2139/ssrn.3022208.

_. 2020b. "Searching for a Roommate: A Correspondence Audit Examining Racial/Ethnic and Immigrant Discrimination among Millennials.” Socius 6 (December). https://doi.org/10.1177/2378023120972287.

Galster, George. 1990a. "Racial Steering by Real Estate Agents: Mechanisms and Motives.” The Review of Black Political Economy 19 (1): 39-63. https://doi.org/10.1007/BF02899931. . 1990b. "Racial Discrimination in Housing Markets during the 1980s: A Review of the Audit Evidence.” Journal of Planning Education and Research 9 (3): 165-75. https://doi.org/10.1177/0739456X9000900302.

Galster, George, and Peter Constantine. 1991. "Discrimination Against Female-Headed Households in Rental Housing: Theory and Exploratory Evidence.” Review of Social Economy 49 (1): 76-100. https://doi.org/10.1080/00346769100000005.

Ghoshal, Raj. 2019. "Flawed Measurement of Hiring Discrimination against African Americans” 18 (2): 10.

Hakken, Jon. 1979. Discrimination Against Chicanos in the Dallas Rental Housing Market: An Experimental Extension of the Housing Market Practices Survey. Department of Housing and Urban Development, Office of Policy Development and Research, Division of Evaluation.

Hanson, Andrew. 2017. "Do College Admissions Counselors Discriminate? Evidence from a Correspondence-Based Field Experiment.” Economics of Education Review 60 (October): 86-96. https://doi.org/10.1016/j.econedurev.2017.08.004.

Hanson, Andrew, and Zackary Hawley. 2011. "Do Landlords Discriminate in the Rental Housing Market? Evidence from an Internet Field Experiment in US Cities.” Journal of Urban Economics 70 (2): 99-114. https://doi.org/10.1016/j.jue.2011.02.003.

Hanson, Andrew, Zackary Hawley, and Aryn Taylor. 2011. "Subtle Discrimination in the Rental Housing Market: Evidence from e-Mail Correspondence with Landlords.” Journal of Housing Economics 20 (4): 276-84. https://doi.org/10.1016/j.jhe.2011.09.003.

Harvey, Hope, Kelley Fong, Kathryn Edin, and Stefanie DeLuca. 2020. "Forever Homes and Temporary Stops: Housing Search Logics and Residential Selection.” Social Forces 98 (4): 1498-1523. https://doi.org/10.1093/sf/soz110.

Hellyer, Joshua. 2021. "Homophobia and the Home Search: Rental Market Discrimination against Same-Sex Couples in Rural and Urban Housing Markets.” Journal of Housing Economics 51 (March): 101744. https://doi.org/10.1016/j.jhe.2020.101744.

Henkels, Jacob. 2020. "Housing Discrimination at the Intersection of Health Condition, Race and Felony Status.” University of North Carolina - Chapel Hill. https://doi.org/10.17615/fmre-cr57.

Hoffman, Lily M., and Barbara Schmitter Heisler. 2021. Airbnb, Short-Term Rentals and the Future of Housing. New York: Routledge.

Hogan, Bernie, and Brent Berry. 2011. "Racial and Ethnic Biases in Rental Housing: An Audit Study of Online Apartment Listings.” City \& Community 10 (4): 351-72. https://doi.org/10.1111/j.1540-6040.2011.01376.x.

James, Franklin J., Betty J. McCummings, and Eileen A. Tynan. 1984. "Minorities in the Sunbelt.” New Brunswick, NJ: Rutgers Univ. Center for Urban Policy Research. 
Johfre, Sasha Shen. 2020. “What Age Is in a Name?” Sociological Science 7 (August): 367-90. https://doi.org/10.15195/v7.a15.

Korver-Glenn, Elizabeth. 2018. "Compounding Inequalities: How Racial Stereotypes and Discrimination Accumulate across the Stages of Housing Exchange.” American Sociological Review 83 (4): 627-56. https://doi.org/10.1177/0003122418781774.

—. 2021. Race Brokers: Housing Markets and Segregation in 21st Century Urban America. Oxford University Press.

Krysan, Maria, and Kyle Crowder. 2017. Cycle of Segregation: Social Processes and Residential Stratification. New York: Russell Sage Foundation.

Lahey, Joanna, and Ryan Beasley. 2018. "Technical Aspects of Correspondence Studies.” In Audit Studies: Behind the Scenes with Theory, Method, and Nuance, edited by S. Michael Gaddis, 81-101. Methodos Series. Cham: Springer International Publishing. https://doi.org/10.1007/978-3-319-71153-9_4.

Larsen, Edvard N. 2020. "Induced Competition in Matched Correspondence Tests: Conceptual and Methodological Considerations." Research in Social Stratification and Mobility, Experimental methods in social stratification research, 65 (February): 100475. https://doi.org/10.1016/j.rssm.2020.100475.

Lauff, Erich, and Steven J. Ingels. 2013. "Education Longitudinal Study of 2002 (ELS: 2002): A First Look at 2002 High School Sophomores 10 Years Later.” NCES 2014-363. Washington, D.C.: National Center for Education Statistics.

Levy, Diane K, Rob Pitingolo, Doug Wissoker, Sarale Sewell, Claudia L Aranda, Rob Santos, and Brent Howell. 2017. "A Paired-Testing Pilot Study of Housing Discrimination against Same-Sex Couples and Transgender Individuals.” The Urban Institute.

Levy, Diane K., Margery Austin Turner, Robert Santos, Doug Wissoker, Claudia L. Aranda, Rob Pitingolo, and Helen Ho. 2015. "Discrimination in the Rental Housing Market Against People Who Are Deaf and People Who Use Wheelchairs: National Study Findings.” The Urban Institute.

Lu, Yao, Neeraj Kaushal, Xiaoning Huang, and S. Michael Gaddis. 2021. "Priming COVID-19 Salience Increases Prejudice and Discriminatory Intent Against Asians and Hispanics.”

Moore, M. Kathleen. 2016. "Lists and Lotteries: Rationing in the Housing Choice Voucher Program.” Housing Policy Debate 26 (3): 474-87. https://doi.org/10.1080/10511482.2015.1129984.

— . 2018. “'I Don't Do Vouchers': Experimental Evidence of Discrimination against Housing Voucher Recipients across Fourteen Metro Areas.” Working paper.

Murchie, Judson, and Jindong Pang. 2018. "Rental Housing Discrimination across Protected Classes: Evidence from a Randomized Experiment.” Regional Science and Urban Economics 73 (November): 170-79. https://doi.org/10.1016/j.regsciurbeco.2018.10.003.

Murphy, Laura W. 2016. “Airbnb’s Work to Fight Discrimination and Build Inclusion: A Report Submitted to Airbnb.” San Francisco, CA: Airbnb.

Oh, Sun Jung, and John Yinger. 2015. "What Have We Learned From Paired Testing in Housing Markets?” Cityscape 17 (3): 15-60.

Olsen, Skylar. 2014. "Doubled up for Dollars.” 2014. http://www.zillow. com/research/doublingup-households-7947/.

Pager, Devah. 2003. “The Mark of a Criminal Record.” American Journal of Sociology 108 (5): 937-75. https://doi.org/10.1086/374403. 
Pedulla, David S. 2016. "Penalized or Protected? Gender and the Consequences of Nonstandard and Mismatched Employment Histories.” American Sociological Review 81 (2): 262-89. https://doi.org/10.1177/0003122416630982. . 2018. "Emerging Frontiers in Audit Study Research: Mechanisms, Variation, and Representativeness." In Audit Studies: Behind the Scenes with Theory, Method, and Nuance, edited by S. Michael Gaddis, 179-95. Methodos Series. Cham: Springer International Publishing. https://doi.org/10.1007/978-3-319-71153-9_9.

Phillips, David C. 2017. "Landlords Avoid Tenants Who Pay with Vouchers.” Economics Letters 151 (February): 48-52. https://doi.org/10.1016/j.econlet.2016.11.036.

Phillips, David C. 2019. "Do Comparisons of Fictional Applicants Measure Discrimination When Search Externalities Are Present? Evidence from Existing Experiments.” The Economic Journal 129 (621): 2240-64. https://doi.org/10.1111/ecoj.12628.

Quadlin, Natasha. 2018. “The Mark of a Woman's Record: Gender and Academic Performance in Hiring.” American Sociological Review 83 (2): 331-60. https://doi.org/10.1177/0003122418762291.

Quillian, Lincoln, Anthony Heath, Devah Pager, Arnfinn Midtbøen, Fenella Fleischmann, and Ole Hexel. 2019. "Do Some Countries Discriminate More than Others? Evidence from 97 Field Experiments of Racial Discrimination in Hiring.” Sociological Science 6: 467-96. https://doi.org/10.15195/v6.a18.

Quillian, Lincoln, John J. Lee, and Brandon Honoré. 2020. "Racial Discrimination in the U.S. Housing and Mortgage Lending Markets: A Quantitative Review of Trends, 1976-2016.” Race and Social Problems 12 (1): 13-28. https://doi.org/10.1007/s12552-019-09276-x.

Quillian, Lincoln, Devah Pager, Ole Hexel, and Arnfinn H. Midtbøen. 2017. "Meta-Analysis of Field Experiments Shows No Change in Racial Discrimination in Hiring over Time." Proceedings of the National Academy of Sciences 114 (41): 10870-75. https://doi.org/10.1073/pnas.1706255114.

Riach, P. A., and J. Rich. 2002. "Field Experiments of Discrimination in the Market Place.” The Economic Journal 112 (483): F480-518. https://doi.org/10.1111/1468-0297.00080.

Rich, Judith. 2014. "What Do Field Experiments of Discrimination in Markets Tell Us? A Meta Analysis of Studies Conducted Since 2000.” SSRN Scholarly Paper ID 2517887. Rochester, NY: Social Science Research Network. https://papers.ssrn.com/abstract=2517887.

Rivera, Lauren A., and András Tilcsik. 2016. "Class Advantage, Commitment Penalty: The Gendered Effect of Social Class Signals in an Elite Labor Market.” American Sociological Review 81 (6): 1097-1131. https://doi.org/10.1177/0003122416668154.

Rosen, Eva. 2020. The Voucher Promise: "Section 8" Housing and the Fate of an American Neighborhood. Princeton, NJ: Princeton University Press. . 2021. “If ‘Housing Is a Right,' How Do We Make It Happen?” Online. New York Times. February 17, 2021. https://www.nytimes.com/2021/02/17/opinion/evictionhousing-biden.html.

Ross, Stephen L., and Margery Austin Turner. 2005. "Housing Discrimination in Metropolitan America: Explaining Changes between 1989 and 2000.” Social Problems 52 (2): 152-80. https://doi.org/10.1525/sp.2005.52.2.152.

Schor, Juliet B., and Steven P. Vallas. 2021. "The Sharing Economy: Rhetoric and Reality.” Annual Review of Sociology 47 (1): null. https://doi.org/10.1146/annurev-soc-082620031411. 
Schwegman, David. 2019. "Rental Market Discrimination Against Same-Sex Couples: Evidence From a Pairwise-Matched Email Correspondence Test.” Housing Policy Debate 29 (2): 250-72. https://doi.org/10.1080/10511482.2018.1512005.

“Settlement Reached in Airbnb Discrimination Case.” 2019. Stoll Berne | Attorneys | ClassAction, Securities, IP, Real Estate, Business Litigation. August 13, 2019. https://stollberne.com/news/settlement-reached-in-airbnb-discrimination-case/.

Stewart, Robert, and Christopher Uggen. 2020. "Criminal Records and College Admissions: A Modified Experimental Audit.” Criminology 58 (1): 156-88. https://doi.org/10.1111/1745-9125.12229.

Thornhill, Ted. 2019. "We Want Black Students, Just Not You: How White Admissions Counselors Screen Black Prospective Students.” Sociology of Race and Ethnicity 5 (4): 456-70. https://doi.org/10.1177/2332649218792579.

Turner, Margery Austin. 2015. "Other Protected Classes: Extending Estimates of Housing Discrimination.” Cityscape 17 (3): 123-36.

Turner, Margery Austin, Carla Herbig, Deborah Kaye, Julie Fenderson, and Diane K. Levy. 2005. "Discrimination Against Persons with Disabilities: Barriers at Every Step.” The Urban Institute.

Turner, Margery Austin, and Judson James. 2015. “Guest Editors’ Introduction: Discrimination as an Object of Measurement.” Cityscape 17 (3): 3-14.

Turner, Margery Austin, and Stephen L Ross. 2003. "Discrimination in Metropolitan Housing Markets Phase II: Asians and Pacific Islanders.” The Urban Institute.

Turner, Margery Austin, Stephen L. Ross, Julie Adams, Beata Bednarz, Carla Herbig, Seon Joo Lee, and Kimberlee Ross. 2003. "Discrimination in Metropolitan Housing Markets: Phase 3: Native Americans: (727472011-001).” American Psychological Association. https://doi.org/10.1037/e727472011-001.

Turner, Margery Austin, Stephen L Ross, George Galster, and John Yinger. 2002. "Discrimination in Metropolitan Housing Markets," 273.

Turner, Margery Austin, Robert Santos, Diane K. Levy, Doug Wissoker, Claudia L. Aranda, and Rob Pitingolo. 2013. "Housing Discrimination Against Racial and Ethnic Minorities 2012.” The Urban Institute.

Turner, Margery Austin, Raymond J. Struyk, and John Yinger. 1991. "Housing Discrimination Study: Summary of Findings.” The Urban Institute.

U.S. Census Bureau. 2017. “American Community Survey 5-Year Estimates. Household Type by Relationships.” Washington, D.C.: U.S. Census Bureau.

Vallas, Steven, and Juliet B. Schor. 2020. "What Do Platforms Do? Understanding the Gig Economy.” Annual Review of Sociology 46: 273-94. https://doi.org/10.1146/annurev-soc121919-054857.

Vuolo, Mike, Christopher Uggen, and Sarah Lageson. 2016. "Statistical Power in Experimental Audit Studies Cautions and Calculations for Matched Tests With Nominal Outcomes.” Sociological Methods \& Research 45 (2): 260-303. https://doi.org/10.1177/0049124115570066. . 2018. "To Match or Not to Match? Statistical and Substantive Considerations in Audit Design and Analysis.” In Audit Studies: Behind the Scenes with Theory, Method, and Nuance, edited by S. Michael Gaddis, 119-40. Methodos Series. Cham: Springer International Publishing. https://doi.org/10.1007/978-3-319-71153-9_6. 
Weichselbaumer, Doris. 2015. “Testing for Discrimination against Lesbians of Different Marital Status: A Field Experiment.” Industrial Relations: A Journal of Economy and Society 54 (1): 131-61. https://doi.org/10.1111/irel.12079.

- 2020. “Multiple Discrimination against Female Immigrants Wearing Headscarves.” ILR Review 73 (3): 600-627. https://doi.org/10.1177/0019793919875707.

Wienk, Ronald E., Clifford E. Reid, John C. Simonson, and Frederick J. Eggers. 1979.

"Measuring Racial Discrimination in American Housing Markets: The Housing Market Practices Survey.” Division of Evaluation, U.S. Department of Housing and Urban Development, Office of Policy Development and Research.

Yinger, John. 1986. "Measuring Racial Discrimination with Fair Housing Audits: Caught in the Act.” The American Economic Review 76 (5): 881-93.

1995. Closed Doors, Opportunities Lost: The Continuing Costs of Housing Discrimination. Russell Sage Foundation.

https://www.jstor.org/stable/10.7758/9781610445627. 